\title{
White-nose syndrome-related changes to Mid-Atlantic bat communities across an urban-to-rural gradient
}

\author{
Sabrina Deeley ${ }^{1 *}$ (D) Joshua B. Johnson², W. Mark Ford ${ }^{3}$ (D) and J. Edward Gates ${ }^{4}$
}

\begin{abstract}
Background: White-nose Syndrome (WNS) has reduced the abundance of many bat species within the United States' Mid-Atlantic region. To determine changes within the National Park Service National Capital Region (NCR) bat communities, we surveyed the area with mist netting and active acoustic sampling (2016-2018) and compared findings to pre-WNS (2003-2004) data.

Results: The results indicated the continued presence of the threatened Myotis septentrionalis (Northern Long-eared bat) and species of conservation concern, including Perimyotis subflavus (Tri-colored bat), Myotis leibii (Eastern Smallfooted bat) and Myotis lucifugus (Little Brown bat). However, we documented a significant reduction in the abundance and distribution of M. lucifugus and P. subflavus, a decrease in the distribution of M. septentrionalis, and an increase in the abundance of Eptesicus fuscus (Big Brown bat).

Conclusions: Documented post-WNS M. septentrionalis recruitment suggests that portions of the NCR may be important bat conservation areas. Decreases in distribution and abundance of $P$. subflavus and $M$. lucifugus indicate probable extirpation from many previously occupied portions of the region.
\end{abstract}

Keywords: Bat, Eptesicus fuscus, Lasiurus borealis, Myotis septentrionalis, Urban environments, White-nose syndrome

\section{Background}

White-nose Syndrome is caused by the psychrophilic fungi Pseudogymnoascus destructans [1-3], an invasive species native to Eurasia [4-8]. White-nose Syndrome has caused widespread mortality of cave-hibernating bats [9-11]. For hibernating bats, fungal invasion of epithelial tissue increased overwinter arousal, leading to a depletion of fat reserves followed by mortality from starvation or, for overwinter survivors, decreased post-hibernating condition, decreased fitness, and shifts in reproductive timing $[9,12-15]$. Since WNS was first observed in New York in 2006, P. destructans has spread to 33 states in the United States (U.S.) and 7 provinces in Canada,

\footnotetext{
* Correspondence: sdeeley@vt.edu

'Department of Fish and Wildlife Conservation, Virginia Tech, Blacksburg, VA 24061, USA

Full list of author information is available at the end of the article
}

including hibernacula presumably used by bats summering within the national capital region (NCR) around Washington, District of Columbia (D.C.) [16]. Based largely on winter hibernacula counts species, such as Myotis lucifugus (Little Brown bat), Myotis septentrionalis (Northern Long-eared bat), Myotis sodalis (Indiana bat), and Perimyotis subflavus (Tri-colored bat), have undergone large population decreases $[10,11,17]$. In the spring, these species migrate from hibernacula to summer habitat [18]. Therefore, summer activity surveys have reflected WNS-caused population declines of M. lucifugus, M. septentrionalis, and M. sodalis in Massachusetts, New Hampshire, New York and West Virginia [12, 14, 19-23].

White-nose Syndrome does not impact all bat species equally. Roosting behaviors, body sizes, hibernacula colony sizes, environmental conditions of particular hibernacula, WNS exposure levels and disease virulence can 
positively or negatively affect survival rates following exposure to WNS [24, 25]. Although WNS can negatively impact Eptesicus fuscus (Big Brown bat) [19], many individuals appear to be unaffected or are able to survive at higher rates than other species, perhaps because their larger body size allows for greater fat reserves than smaller bat species [26], or they are hibernating within warmer anthropogenic roosts unfavorable to growth of $P$. destructans [27]. Despite high mortality rates, remnant populations of M. lucifugus, $M$. septentrionalis, $M$. sodalis, and $P$. subflavus can persist in WNS-affected areas [28-30].

When populations experience declines or extirpation, competitive release may result in other species altering their habitat use, increasing their range, or increasing their population size; for example, some relaxation in niche partitioning has been observed for bats in WNSimpacted landscapes [31]. Along the East Coast, increases in E. fuscus, Lasiurus borealis (Eastern Red bat), and Lasiurus cinereus (Hoary bat) have corresponded with decreases in M. lucifugus, M. septentrionalis, M. sodalis and P. subflavus $[12,19,31]$. However, total intra-night activity indicated that other bat species were not expanding into temporal niches formerly dominated by $M$. lucifugus postWNS [23, 31].

Urban environments can increase contact between individuals because of highly-concentrated resources, such as limited foraging patches and limited day-roost availability, or impact individuals' physical condition through use of marginal day roosts, increased competition for food resources, and pollution [32]. Urbanization can impact bat activity patterns and foraging ecology [33]. Therefore, urbanization may exacerbate winter WNS population declines, as better body condition entering hibernation can increase WNS survival [34, 35] or compound WNScaused population declines with urbanization-caused decreases in reproductive success [12, 15, 29, 36]. Additionally, highly-urbanized areas often have lower bat diversity and activity levels than less-developed, rural, semi-natural, or natural areas [36-43].

Hibernacula near the NCR have shown large declines in $M$. lucifugus, $M$. sodalis, and P. subflavus populations $[17,44]$. Accordingly, we sought to document how summer bat communities and habitat associations in the NCR have changed since WNS onset, in terms of overall bat activity and changes to community membership. In 20032004, Johnson et al. [45] surveyed bat communities within 11 NCR National Park Service (NPS) units to assess community patterns along an urban-to-rural gradient using a combined active acoustic and mist-netting sample approach. Both methods allow for detection of bat species and evaluation of relative activity or abundance. Acoustic sampling records bat echolocation calls that can be identified to species, and mist netting captures and identifies individual bats [46].
Our first objective was to compare the sampling effort required to document presence of species pre- and postWNS. We expected that the effort required to document the same species would be higher post-WNS than preWNS [46]. Our second objective was to determine the impacts of WNS on bat communities within the NCR by considering relative abundance measures and distribution of detections in the NCR. We predicted shifts in NCR community structure relative to the pre-WNS findings of Johnson et al. [45], including possible population decreases, population extirpations, and reduced distribution of species highly impacted by WNS (M. lucifugus, M. septentrionalis, M. sodalis, and P. subflavus). Competitive release of larger-bodied, less-affected species, such as E. fuscus, or non-hibernating migratory species, such as L. borealis, could result in increased abundance or changes in habitat associations. Similar to Johnson et al. [45], we predicted that the highest species richness would be found in less-fragmented, rural habitats with more forest cover, as fewer bat species occurred within higher urbanization levels.

\section{Methods}

\section{Study area}

Our study area consisted of the 11 NPS units that Johnson et al. [45] surveyed 2003-2004: Antietam National Battlefield (ANTI), Catoctin Mountain Park (CATO), Chesapeake and Ohio Canal National Historical Park $(\mathrm{CHOH})$, George Washington Memorial Parkway (GWMP), Harpers Ferry National Historical Park (HAFE), Manassas National Battlefield Park (MANA), Monocacy National Battlefield (MONO), National Capital Parks-Central (now National Mall and Memorial Parks [NAMA]), National Capital Parks-East (NACE), Rock Creek Park (ROCR) and Wolf Trap National Park for the Performing Arts (WOTR; Fig. 1). The area covers portions of the Coastal Plain $(\mathrm{CHOH}, \mathrm{GWMP}, \mathrm{NACE}$, NAMA), Piedmont (CHOH, GWMP, MANA, MONO, ROCR, WOTR), Blue Ridge Mountains (CATO, $\mathrm{CHOH}$, HAFE) and Ridge and Valley (ANTI, CHOH, HAFE) physiographic regions in D.C., Maryland, Virginia, and West Virginia. Elevations in the sampled sites ranged from sea level to $730 \mathrm{~m}$, with higher elevations and more complex topography in the western Blue Ridge and Ridge and Valley regions. From May to August 20032004 and 2016-2018, temperatures during sampling ranged from minima of $2.1-25.4{ }^{\circ} \mathrm{C}$ and maxima of $14.6-35.6^{\circ} \mathrm{C}$. Precipitation ranged from 290 to $1157 \mathrm{~mm}$ per season, but was highly variable among years, with 2018 receiving more precipitation than other years. White-nose Syndrome was first confirmed in the area over the 2009-2010 winter period [16].

The region includes forests, pasture areas, suburban development, and high-density urban development. The 


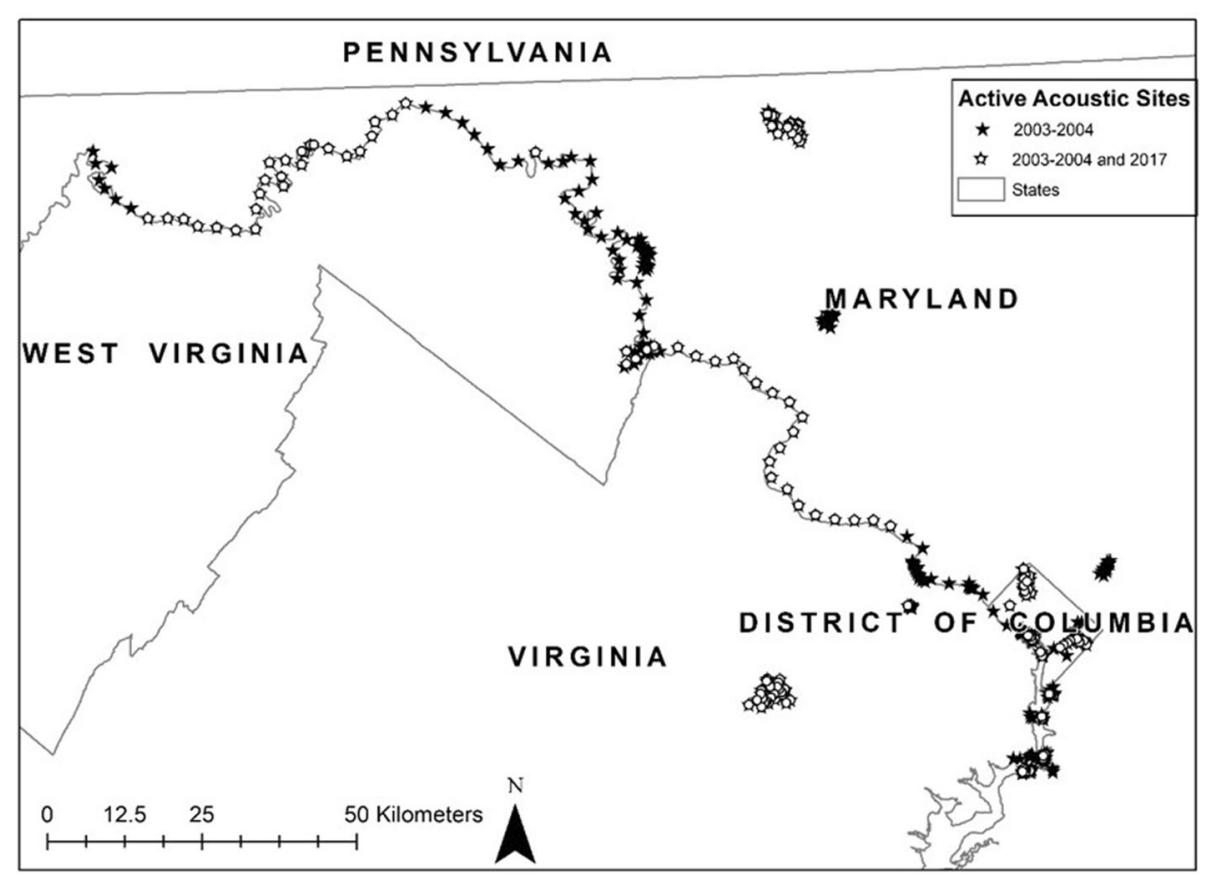

Fig. 1 National Park Service National Capital Region acoustic survey sites during pre-White-nose Syndrome (2003-2004) and post-White-nose Syndrome (2016-2018) periods. Black stars indicate sites surveyed 2003-2004, and open stars indicate sites surveyed in both $2003-2004$ and 2017. Park abbreviations are: Antietam National Battlefield (ANTI), Catoctin Mountain Park (CATO), Chesapeake and Ohio Canal National Historical Park $(\mathrm{CHOH})$, George Washington Memorial Parkway (GWMP), Harpers Ferry National Historical Park (HAFE), Manassas National Battlefield Park (MANA), Monocacy National Battlefield (MONO), National Capital Parks-Central [now National Mall and Memorial Parks (NAMA)], National Capital Parks-East (NACE), Rock Creek Park (ROCR), and Wolf Trap National Park for the Performing Arts (WOTR). CHOH follows the Maryland border with Virginia and West Virginia from the western-most part of the study area to downtown District of Columbia (D.C.) between the two CHOH points. NACE and GWMP points indicate the southern-most and northern-most parks within those units. Parks partially or entirely within D.C. include ROCR, $\mathrm{CHOH}, \mathrm{NAMA}$, and NACE

study area largely has an east-west (and, to a lesser extent, south-north) urban-to-rural gradient. The most rural portions of the study area include CATO (a contiguous forest unit surrounded by both private and public forestland) and northwestern portions of $\mathrm{CHOH}$ in central and western Maryland. As the longest unit with the most habitat variation, $\mathrm{CHOH}$ follows the D.C. and Maryland border with Virginia and West Virginia from downtown D.C., through suburban development, agricultural fields, and private and state forests and wildlife management areas to Cumberland, Maryland. The $\mathrm{CHOH}$ is adjacent to HAFE (a mix of rural mountainous forest and open battlefields), near ANTI and MONO, and adjacent to small portions of GWMP. The battlefield units (ANTI, MANA, MONO) consist mainly of agricultural fields and small forest woodlots. As a performing arts center, WOTR is a combination of developed land and forest fragments surrounded by a developed suburban landscape. Near D.C., GWMP primarily follows the Virginia border and Potomac River. It contains larger contiguous forest stands (e.g., Great Falls Park, approximately $13 \mathrm{~km}$ north of D.C.) and linear forest strips along motorways. Units partially or entirely within D.C. (ROCR, CHOH, NAMA,
NACE) are highly fragmented, with the exception of ROCR. This unit primarily consists of 2 large contiguous forested patches which follow 2 water courses to the Potomac River, Rock Creek and Foundry Branch [47]. Dominated by open areas and National Mall monuments, NAMA contains minimal forest cover. The parks of NACE include units on the southeastern bank of the Anacostia River, as well as a thin linear forest strip running along the BaltimoreWashington Parkway up to Greenbelt Park, a small contiguous forest stand northeast of the city.

Currently, the region is dominated by a mix of oakhickory and mesophytic forest types, e.g., Quercus spp. (oak species), Acer spp. (maple species), Liriodendron tulipifera (yellow poplar) and to a lesser extent Pinus spp. (pine species) [48]. Within the NCR units, forest stands primarily consisted of mature and late successional forests, more so than the surrounding landscape [47]. Deciduous tree species that dominate the upland areas on NCR units include Acer rubrum (Red Maple), Fagus grandifolia (American Beech), L. tulipifera, and Quercus spp. Riparian forests along larger watercourses contain Platanus occidentalis (Sycamore), Acer negundo (Boxelder), and Liquidambar styraciflua (Sweetgum). 


\section{Acoustic and mist-netting surveys}

We replicated the active acoustic methods used by Johnson et al. [45] to allow a direct comparison of echolocation call data between 2003 and 2004 (pre-WNS) and 2017 (post-WNS). Using the same acoustic recording methods was important for directly comparing preWNS call data recorded to post-WNS call data, as the methods can impact detection and habitat associations [49]. We used Anabat II (Titley Electronics, Ballina, Australia) zero-crossing, frequency-division equipment to actively survey at each sample site for one 20-min period between sunset and 0200. If a bat was "observed" as evidenced by audible echolocation sounds from the recorder or by sight, we attempted to follow its direction with the microphone to record a high-quality call sequence [50]. Active survey sites were in forested, wetland, and open habitats with a mean distance between survey locations of $886 \mathrm{~m} \pm 982 \mathrm{~m}$ [45]. We avoided active acoustic recording and netting during heavy precipitation or low temperatures, as these can reduce bat activity [51].

In 2003 and 2004, we surveyed 362 sites, and in 2017, we revisited 147 sites (40.6\%; Fig. 1). All echolocation calls (2003-2004 and 2017) were identified to species using the U.S Fish and Wildlife Service approved Kaleidoscope 4.5.0 Bats of North America 4.2.0 classifier (Wildlife Acoustics, Inc., Concord, MA, USA) with the following species considered as known or possibly extant in the NCR: E. fuscus, Lasiurus borealis, Lasiurus cinereus, Lasionycteris noctivagans, Myotis leibii (Eastern Small-footed bat), M. lucifugus, M. septentrionalis, $M$. sodalis, Nycticeius humeralis (Evening bat) and P. subflavus. We used the number of echolocation calls identified to species as response variables in statistical analyses.

We mist-netted from 28 May - 29 August in 2003 and 2004 (pre-WNS), as outlined in Johnson et al. [45]. Between 20 April and 10 August 2016-2018 (postWNS), we conducted mist-netting in these same NPS units, and in some cases in the same survey locations. Most post-WNS sampling effort was 15 May - 15 August, per the Range-wide Indiana Bat Survey Guidelines [52]. Post-WNS, netting locations were selected both to provide a general survey of the region and additional effort in areas with acoustic and mist-netting detections of M. lucifugus, $M$. septentrionalis, $M$. sodalis and $P$. subflavus $[43,53]$. Because of post-WNS captures of M. septentrionalis at ROCR [53], we allocated additional effort there in 2018. We placed mist nets along possible flight corridors, e.g., trails, roads with forest canopy cover, and/or near water. The number and size of nets varied by forest structure and logistics. Bat capture and handling procedures were approved under Virginia Tech Institutional Animal Care and Use protocol 16-049 and allowed under USFWS \#TE34778A-2, Maryland
Department of Natural Resources \#56152, Virginia Department of Game and Inland Fisheries \#061519, and West Virginia Division of Natural Resources \#2018.180 scientific collecting permits. We identified bats to species using a dichotomous key to the bats of this region [54], and recorded sex, age (adult or juvenile), and reproductive condition $[55,56]$. We disregarded samples when heavy precipitation or fog event (as defined by onthe-ground observations) disrupted sampling.

\section{Data analysis}

We developed species accumulation curves for both our acoustic and netting datasets, which provided an assessment of species richness based on the level of sample effort [57]. We developed species accumulation curves for each pre- or post-WNS dataset using the $\mathrm{R}$ package vegan with random selection [58]. In the two acoustic species-accumulation curves, we used all samples and 10 acoustically-detected species. For the pre- and postWNS species accumulation curves based on mist-net sampling, we selected the nights with at least $4 \mathrm{~h}$ of netting and no precipitation within the netting event, based on on-the-ground observations. We created 2 sets of species accumulation curves for the netting data: 1 with the 6 species that were found both pre- and post-WNS and 1 for all 9 species captured post-WNS.

To determine whether the number of echolocation calls and number of bat captures for each species changed based on WNS, we performed paired and unpaired $t$-tests in program R [59-61]. We used paired $t$-tests for all acoustic sites that were sampled both pre- and postWNS. We used unpaired t-tests for analysis of all netting sample data because we did not resample the exact same locations pre- and post-WNS. The netting $t$-tests used nightly captures per net to account for higher netting efforts post-WNS.

\section{Results}

We recorded 4967 echolocation calls (2003-2004= $3637 ; 2017=1330$ ), which were identified to 10 species (Table 1). Species richness declined in every NPS unit except NACE, with all units losing detections of at least 1 species severely impacted by WNS (Table 2). PreWNS survey years had higher proportions of nights with identified bat echolocation calls $(2003=80.0 \%, 2004=$ $82.9 \%)$ than the post-WNS sample year $(2017=69.4 \%$; Table 1).

Mist-net sampling varied greatly among years: there were more post-WNS than pre-WNS capture events $(2003=34,2004=40,2016=13,2017=50,2018=98)$ and later years had higher proportions of nights with bat captures $\quad(2003=61.8 \%, \quad 2004=85.0 \%, \quad 2016=76.9 \%$, $2017=86.0 \%, 2018=92.5 \%)$. In 2017 and 2018, netting often had $33-100 \%$ more nets per night than pre-WNS 
Table 1 The total number of active acoustic survey samples with presence of each species (Sites), total bat echolocation calls (Total), and mean and standard error (SE) of bat echolocation calls per active acoustic sample. Samples were collected 2003-2004 and 2017 in the National Park Service National Capital Region. Mean change is the 2017 mean minus the 2003-2004 mean. P-values were from Pearson's paired t-test. Calls were identified to species by using Kaleidoscope 4.5.0 Bats of North America 4.2.0 classifier (Wildlife Acoustics Inc., Concord, MA, USA) for the following species: Eptesicus fuscus (Big Brown bat; EPFU), Lasiurus borealis (Eastern Red bat; LABO), Lasiurus cinereus (Hoary bat; LACI), Lasionycteris noctivagans (Silver-haired bat; LANO), Myotis leibii (Eastern Small-footed bat; MYLE), Myotis lucifugus (Little Brown bat; MYLU), Myotis septentrionalis (Northern-Long eared bat; MYSE), Myotis sodalis (Indiana bat; MYSO), Nycticeius humeralis (Evening bat; NYHU) and Perimyotis subflavus (Tri-colored bat; PESU)

\begin{tabular}{|c|c|c|c|c|c|c|c|c|}
\hline \multirow[t]{2}{*}{ Species code } & \multicolumn{3}{|c|}{$2003-2004$} & \multicolumn{3}{|l|}{2017} & \multirow[t]{2}{*}{ Mean change } & \multirow[t]{2}{*}{$P$-value } \\
\hline & Sites & Total & Mean (SE) & Sites & Total & Mean (SE) & & \\
\hline EPFU & 139 & 889 & $2.46(0.40)$ & 60 & 679 & $4.62(0.96)$ & 2.16 & 0.01 \\
\hline$\angle A B O$ & 77 & 151 & $0.42(0.06)$ & 39 & 104 & $0.71(0.17)$ & 0.29 & 0.07 \\
\hline $\mathrm{LACl}$ & 125 & 496 & $1.37(0.21)$ & 35 & 85 & $0.58(0.13)$ & -0.79 & 0.07 \\
\hline LANO & 150 & 878 & $2.43(0.34)$ & 55 & 251 & $1.71(0.32)$ & -0.72 & 0.86 \\
\hline MYLE & 17 & 23 & $0.06(0.02)$ & 1 & 1 & $0.01(0.01)$ & -0.05 & 0.05 \\
\hline MYLU & 106 & 573 & $1.58(0.33)$ & 29 & 66 & $0.44(0.09)$ & -1.14 & 0.00 \\
\hline MYSE & 28 & 48 & $0.13(0.03)$ & 1 & 13 & $0.09(0.08)$ & -0.04 & 0.33 \\
\hline MYSO & 28 & 77 & $0.21(0.05)$ & 8 & 9 & $0.06(0.02)$ & -0.15 & 0.01 \\
\hline NYHU & 54 & 108 & $0.30(0.52)$ & 34 & 94 & $0.64(0.18)$ & 0.34 & 0.13 \\
\hline PESU & 81 & 394 & $1.09(0.21)$ & 14 & 28 & $0.19(0.07)$ & -0.90 & 0.01 \\
\hline
\end{tabular}

surveys, and these years focused on areas where previous passive acoustic surveys had documented presence of species highly impacted by WNS [53], likely increasing the likelihood of capture of rare species. Six species were captured both pre- and post-WNS, and only in postWNS years, we captured Lasionycteris noctivagans, $M$. leibii, and N. humeralis (Tables 2 and 3). Post-WNS, we captured $M$. lucifugus and P. subflavus only in northwestern Maryland $(\mathrm{CHOH})$, and their absences from all other units were the primary drivers to post-WNS decreases in unit-level species richness for both netting and acoustics data (Table 2). We noted no evidence of reproduction in the $M$. lucifugus and P. subflavus captures, and we only documented evidence of reproduction (pregnant and lactating females) and successful recruitment (juvenile bats) in $M$. septentrionalis populations within ROCR.

Acoustic species accumulation curves indicated that more effort was required to detect all species post-WNS than pre-WNS, despite more capture success post-WNS. Pre-WNS, 94 active acoustic samples were required to document a species richness of $10(\mathrm{SD} \pm 0)$, whereas post-WNS, the species richness was $9.31(\mathrm{SD} \pm 0.68)$ for the same effort (Fig. 2). Even with the focused postWNS surveys, pre-WNS netting required 65 netting nights for a species richness of $6(\mathrm{SD} \pm 0)$, but that effort for the same 6 species post-WNS yielded a species richness of 5.07 ( $\mathrm{SD} \pm 0.76$; Fig. 2). For the post-WNS netting species accumulation curve of all 9 extant species captured, 65 nights yielded a species richness of 7.28 ( $\mathrm{SD} \pm 1.20$; Fig. 2). All 3 post-WNS species accumulation curves required almost every sample included in the analysis in order to reach the maximum species richness with a standard deviation of 0 (acoustics $=147$, both netting = 109).

Based on $t$-tests and overall detections, we observed significant post-WNS increases in E. fuscus and significant distribution decreases occurred for $M$. lucifugus and $P$. subflavus $(P<0.05$; Tables 1 and 3$)$. We also observed significant post-WNS increases in the mean number of captures of Lasionycteris noctivagans and decreases in the recorded acoustic calls for M. leibii and M. sodalis (Tables 1 and 3). Both pre- and postWNS netting results indicated that species richness was highest in western portions of $\mathrm{CHOH}$, where the NCR is the least urbanized and contains the highest proportions of rural and forested landscapes. However, we did not determine a uniformly-negative trend with regard to urbanization, as we also recorded high species richness in highly-urban units. We captured all M. septentrionalis in ROCR, except for a single capture in CATO; $76.9 \%$ of $L$. noctivagans in ROCR $(n=10)$; and all but $1 N$. humeralis in GWMP (Great Falls Park). Eptesicus fuscus were active throughout the NCR, with the least activity coinciding with open, agricultural, or suburban portions of $\mathrm{CHOH}, \mathrm{MONO}$, and MANA. Most activity was in the D.C. area within the larger contiguous forested portions of ROCR and NACE. We captured more Lasiurus borealis west of Great Falls Park (along the geological fall line between the Piedmont and Coastal Plain); however, distribution varied greatly across the landscape. 
Table 2 Species richness documented through active acoustic and mist-net sampling in National Park Service National Capital Region units 2003-2004 and 2016-2018. Species lost indicate species that were documented 2003-2004 but not 2016-2018. Species gained are those species documented in 2016-2018 but not 2003-2004. Note that sample effort by unit was not equal between 2003 and 2004 and 2016-2018. Unit abbreviations are: Antietam National Battlefield (ANTI), Catoctin Mountain Park (CATO), Chesapeake and Ohio Canal National Historical Park (CHOH), George Washington Memorial Parkway (GWMP), Harpers Ferry National Historical Park (HAFE), Manassas National Battlefield Park (MANA), Monocacy National Battlefield (MONO), National Capital ParksCentral [now National Mall and Memorial Parks (NAMA)], National Capital Parks-East (NACE), Rock Creek Park (ROCR), and Wolf Trap National Park for the Performing Arts (WOTR). Species abbreviations are: Eptesicus fuscus (Big Brown bat; EPFU), Lasiurus borealis (Eastern Red bat; LABO), Lasiurus cinereus (Hoary bat; LACI), Lasionycteris noctivagans (Silver-haired bat; LANO), Myotis leibii (Eastern Small-footed bat; MYLE), Myotis lucifugus (Little Brown bat; MYLU), Myotis septentrionalis (Northern Long-eared bat; MYSE), Nycticeius humeralis (Evening bat; NYHU) and Perimyotis subflavus (Tri-colored bat; PESU)

\begin{tabular}{|c|c|c|c|c|c|}
\hline \multirow[t]{2}{*}{ Sample method } & \multirow[t]{2}{*}{ Unit } & \multicolumn{2}{|c|}{ Species richness } & \multirow[t]{2}{*}{ Species lost } & \multirow[t]{2}{*}{ Species gained } \\
\hline & & 2003-2004 & 2016-2018 & & \\
\hline \multirow[t]{11}{*}{ Acoustics } & ANTI & 9 & N/A & N/A & N/A \\
\hline & CATO & 10 & 8 & MYLE, MYSE & \\
\hline & $\mathrm{CHOH}$ & 10 & 8 & MYLE, MYSE & \\
\hline & GWMP & 10 & N/A & N/A & N/A \\
\hline & HAFE & 8 & 2 & EPFU, LACI, LANO, MYLU, MYSO, PESU & \\
\hline & MANA & 10 & 8 & MYSE, MYSO & \\
\hline & MONO & 7 & N/A & N/A & N/A \\
\hline & NAMA & 6 & 5 & PESU & \\
\hline & NACE & 8 & 8 & MYSO & MYSE \\
\hline & $\mathrm{ROCR}$ & 8 & 7 & MYSE & \\
\hline & WOTR & 8 & 1 & EPFU, LABO, LANO, MYLU, MYSE, NYHU, PESU & \\
\hline \multirow[t]{11}{*}{ Netting } & ANTI & 3 & 2 & MYLU & \\
\hline & CATO & 4 & 3 & MYLU & \\
\hline & $\mathrm{CHOH}$ & 6 & 7 & MYSE, LACI & MYLE, NYHU, LANO \\
\hline & GWMP & 4 & 3 & MYLU, PESU & NYHU \\
\hline & HAFE & 3 & 3 & MYSE & $\mathrm{LACl}$ \\
\hline & MANA & 3 & 2 & PESU & \\
\hline & MONO & 4 & 2 & MYLU, PESU & \\
\hline & NAMA & 1 & 1 & LABO & EPFU \\
\hline & NACE & 2 & 2 & & \\
\hline & $\mathrm{ROCR}$ & 6 & 4 & MYLU, PESU, LACI & LANO \\
\hline & WOTR & 2 & 1 & $\angle A B O$ & \\
\hline
\end{tabular}

\section{Discussion}

We determined that active acoustic sampling, as employed in this study, was not suitable for detecting rare bat species on the current post-WNS landscape. Our species accumulation curves reflect decreases in WNS-impacted bat species and higher variation in detections. Similarly, other studies have reported that postWNS sampling effort should be higher than pre-WNS efforts [46, 62]. The small sampling window for active acoustic methods likely limited detection, especially post-WNS. The limitations of our active acoustic sampling are underscored by not observing post-WNS $M$. septentrionalis echolocation calls in ROCR, whereas our mist-netting results indicated continued presence. There was also a non-significant decline in M. septentrionalis echolocation calls across the NCR, despite our capture data indicating a significant decline in post-WNS occurrence. Although our active acoustic sampling techniques may continue to be options for comparing community activity to historical data $[46,63]$ or for detecting common bats, the sampling period for these methods appears inadequate to fully document post-WNS bat communities.

We recorded significant declines in relative abundance and distribution of WNS-impacted species M. lucifugus and $P$. subflavus. These results are similar to those of other summer surveys comparing pre- to post-WNS activity within the northeastern U.S. [21-23]. Though our 
Table 3 The total number of each species captured (Total Captures), total per mist-net (Total), and mean and standard error (SE) of bat captures per mist-net 2003-2004 and 2016-2018 in the National Park Service National Capital Region. Mean change is the 20162018 mean minus the 2003-2004 mean of each species. P-values are from Pearson's t-test. Bat species are: Eptesicus fuscus (Big Brown bat; EPFU), Lasiurus borealis (Eastern Red bat; LABO), Lasiurus cinereus (Hoary bat; LACI), Lasionycteris noctivagans (Silver-haired bat; LANO), Myotis leibii (Eastern Small-footed bat; MYLE), Myotis lucifugus (Little Brown bat; MYLU), Myotis septentrionalis (Northern Long-eared bat; MYSE), Nycticeius humeralis (Evening bat; NYHU) and Perimyotis subflavus (Tri-colored bat; PESU)

\begin{tabular}{|c|c|c|c|c|c|c|c|}
\hline \multirow[t]{2}{*}{ Species code } & \multirow[t]{2}{*}{ Total captures } & \multicolumn{2}{|c|}{$2003-2004$} & \multicolumn{2}{|c|}{$2016-2018$} & \multirow[t]{2}{*}{ Mean change } & \multirow[t]{2}{*}{$P$-value } \\
\hline & & Total & Mean (SE) & Total & Mean (SE) & & \\
\hline EPFU & 958 & 39.73 & $0.54(0.10)$ & 165.77 & $1.03(0.11)$ & 0.49 & 0.01 \\
\hline$\angle A B O$ & 181 & 19.95 & $0.27(0.06)$ & 24.01 & $0.15(0.02)$ & -0.12 & 0.20 \\
\hline LACl & 4 & 0.92 & $0.01(0.01)$ & 0.14 & $0.00(0.00)$ & -0.01 & 0.25 \\
\hline LANO & 13 & 0.00 & $0.00(0.00)$ & 2.40 & $0.01(0.01)$ & 0.01 & 0.01 \\
\hline MYLE & 1 & 0 & $0.00(0.00)$ & 0.17 & $0.00(0.00)$ & 0.00 & 0.32 \\
\hline MYLU & 108 & 33.8 & $0.46(0.17)$ & 0.47 & $0.00(0.00)$ & -0.46 & 0.01 \\
\hline MYSE & 51 & 6.95 & $0.09(0.03)$ & 4.83 & $0.03(0.01)$ & -0.06 & 0.2 \\
\hline $\mathrm{NYHU}$ & 4 & 0 & $0.00(0.00)$ & 0.68 & $0.00(0.00)$ & 0.00 & 0.31 \\
\hline PESU & 34 & 10.5 & $0.14(0.04)$ & 0.17 & $0.00(0.00)$ & -0.14 & 0.00 \\
\hline
\end{tabular}

analyses did not document a significant change in $M$. septentrionalis capture rates, this non-significance is likely the result high post-WNS mist-netting sampling density in ROCR, which may have introduced a overlyconservative bias in our comparison. Nonetheless, we still observed a decrease in distribution throughout the study area.

Increases in post-WNS E. fuscus activity in the NCR aligned with documented stable populations in New York summer habitat 2004-2010 [21], 43\% increases in a New York hibernaculum 2-3 years after WNS detection [26] and $12 \%$ increases in captures approximately 1-3 years after WNS detection in Indiana [29]. Eptesicus fuscus populations may have avoided WNS-related declines based on hibernation conditions, e.g., uninfected hibernacula, temperature within hibernacula or shorter hibernation periods, as well as being physiologically less challenged by or resistant to $P$. destructans $[24,25,64$, 65]. Lasiurus borealis activity was similar between preand post-WNS sampling periods, indicating no expansion into WNS-emptied habitat niches [31] or potential wind-energy driven population declines [66]. Our results are similar to those of pre-WNS versus post-WNS comparisons of bat communities in South Carolina and New York [23, 67].

Whereas urbanization influenced some species' distributions, it has not appeared to have exacerbated WNS declines. We found our only evidence of recruitment among highly WNS-impacted species in D.C. Some combination of disease resistance, summer habitat, overwintering patterns and a small pre-WNS population of WNS-susceptible species may have led to ROCR being a potential M. septentrionalis refugium within the Mid-
Atlantic region. Pre-WNS, both $M$. septentrionalis and $M$. lucifugus captures were relatively rare in ROCR compared to most other units, yet $M$. septentrionalis populations appear to be successfully reproducing only within ROCR. Although $M$. septentrionalis' survival mechanisms are not yet known, remnant $M$. lucifugus populations along the East Coast have exhibited genetically based resistance and avoidance behavior that may reduce WNS impacts $[28,68]$. As a mostly-contiguous unit with oldergrowth, late-successional forest [47], ROCR contained a diverse mix of tree sizes and a high density of large standing snags and trees with cavities and bark conditions conducive to $M$. septentrionalis day-roosting. Given the mature forest, year-round water sources, and surrounding established neighborhoods with numerous tree and anthropogenic day-roost opportunities, ROCR may provide an optimal balance of forest and edge habitat, access to water resources, and both natural and anthropogenic roosting and hibernacula options. Recent overwinter detections of $M$. septentrionalis along coastal areas to the southeast of ROCR [69-72] provide evidence that some individuals are not migrating to $P$. destructans-infected hibernacula to the west in the Appalachian Mountains. The authors' capture of a M. septentrionalis in ROCR on 1 November 2018 provides additional support for this hypothesis. In the more easterly urban areas, we observed slightly higher E. fuscus activity overall. Our E. fuscus results are similar to those of a landscape-scale survey in Georgia and the Carolinas that reported higher E. fuscus abundance within NPS units with high levels of developed land within $5 \mathrm{~km}$ [73]. Still, within the D.C. area, we saw higher activity within larger forest patches, similar to observations in Mexico City [38]. 

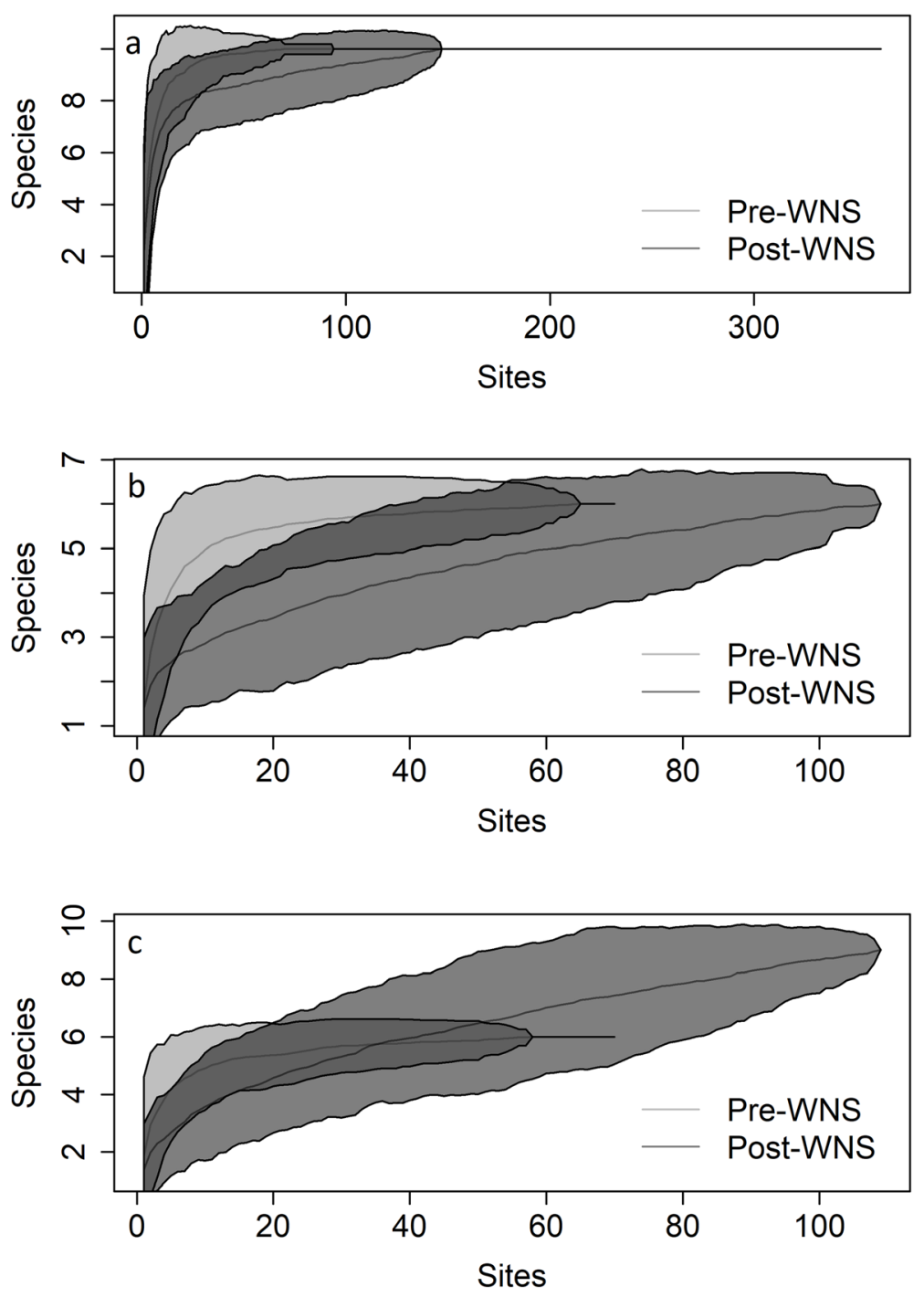

Fig. 2 Species accumulation curves for active acoustic and mist netting surveys in the National Park Service National Capital Region $2003-2018$. Darker lines and polygons are 2003-2004 samples and standard deviations, and lighter lines and polygons are 2016-2018 samples and standard deviations with a acoustic sampling both 2003-2004 and 2017; b mist netting with only 6 species captured 2003-2004; and c mist netting with all 9 species captured $2003-2004$ and 2016-2018

We suggest caution regarding the interpretation of pre- and post-WNS comparisons in the NCR and other WNS-affected regions. When comparing post-WNS communities to pre-WNS communities, it is necessary to be cognizant of how improved sampling methods have potentially increased detection and capture rates, whether through compliance with USFWS $M$. sodalis survey guidelines [52] or technological improvements (e.g., passive vs. active acoustics, use of automated identification software, netting equipment). Documented bat echolocation calls and capture rates also may have been influenced by the habitat structure in more urban, fragmented forest stands, with travel corridors concentrating bat activity more than in largely forested landscapes. Moreover, annual weather variation may have influenced differences in acoustic and capture data as well as yearto-year demographic changes [74-76]; 2018 had the most netting samples and had higher levels of precipitation than any other year. The differences in pre- and post-WNS netting species accumulation curves are likely greater than the species accumulation curves demonstrate, as differences in netting effort on each sample night were unaccounted for.

\section{Conclusions}

Based on the documented declines in bat passes and capture rates of $M$. lucifugus and $P$. subflavus populations, these species may be functionally extirpated throughout much of the NCR. Acoustic echolocation calls and netting capture rates for E. fuscus increased 
significantly. Consequently, long-term monitoring would be required in the region to determine E. fuscus population increases, and intensive future surveys would be required to assess possible habitat expansion of bats less impacted by WNS (E. fuscus and L. borealis) into vacant niches. Furthermore, additional assessments in the MidAtlantic region are needed to determine whether or how $M$. septentrionalis persistence is linked to atypical overwintering activities, such as use of coastal forests to the east and southeast of the NCR rather than cave hibernacula, high-quality maternity habitat conditions in residual NCR forest patches, or other genetic or behavioral resistance mechanisms.

\begin{abstract}
Abbreviations
ANTI: Antietam National Battlefield; CATO: Catoctin Mountain Park; CHOH: Chesapeake and Ohio Canal National Historical Park; D.C.: District of Columbia; GWMP: George Washington Memorial Parkway; HAFE: Harpers Ferry National Historical Park; MANA: Manassas National Battlefield Park; MONO: Monocacy National Battlefield; NAMA: National Mall and Memorial Parks; NACE: National Capital Parks-East; NCR: National Capital Region; NPS: National Park Service; ROCR: Rock Creek Park; WNS: White-nose Syndrome; WOTR: Wolf Trap National Park for the Performing Arts
\end{abstract}

\section{Acknowledgements}

Special thanks goes to L. Rohrbaugh for assistance throughout this study. Fieldwork was performed by T. Calhoun, E. Barr, S. Dermody, S. Freeze, R. Lesagonicz, G. Mosley, A. Morrison, A. Silvis, H. Taylor, and V. Wolfgang.

\section{Authors' contributions}

SD, WF, JJ and JG conducted field work to collect the data used for this study. SD and WF were major contributors to the manuscript. All authors have read and approved the manuscript.

\section{Funding}

The 2016-2018 work was funded by the National Park Service Natural Resources Preservation Program (NRPP) and WNS Support programs through Southern Appalachian and Chesapeake Bay Cooperative Ecosystem Study Unit grants P16AC00821 and P17AC01616 to the Virginia Tech Department of Fish and Wildlife Conservation. Additional in-kind support was provided by the U.S. Geological Survey Cooperative Research Unit program, Maryland Department of Natural Resources, Virginia Department of Game and Inland Fisheries and the District of Columbia Department of Energy and Environment.

\section{Availability of data and materials}

The datasets used and/or analyzed during the current study are available from the corresponding author on reasonable request.

\section{Declarations}

Ethics approval and consent to participate

Bat capture and handling procedures were approved under Virginia Tech Institutional Animal Care and Use protocol 16-049. Any use of trade, firm, or product names is for descriptive purposes only and does not imply endorsement by the U.S. Government.

\section{Consent for publication}

Not applicable.

\section{Competing interests}

The authors declare that they have no competing interests.

\section{Author details}

'Department of Fish and Wildlife Conservation, Virginia Tech, Blacksburg, VA 24061, USA. ${ }^{2}$ Pennsylvania Game Commission, Harrisburg, PA 17110, USA.

${ }^{3}$ U.S. Geological Survey, Virginia Cooperative Fish and Wildlife Research Unit,
Blacksburg, VA 24061, USA. ${ }^{4}$ University of Maryland Center for Environmental Science, Appalachian Laboratory, Frostburg, MD 21532, USA.

Received: 12 February 2020 Accepted: 20 April 2021

Published online: 07 May 2021

\section{References}

1. Verant ML, Boyles JG, Waldrep W, Wibbelt G, Blehert DS. Temperaturedependent growth of Geomyces destructans, the fungus that causes bat white-nose syndrome. PLoS One. 2012;7(9):e46280. https://doi.org/10.1371/ journal.pone.0046280.

2. Lorch JM, Meteyer CU, Behr MJ, Boyles JG, Cryan PM, Hicks AC, et al. Experimental infection of bats with Geomyces destructans causes white-nose syndrome. Nature. 2011;480(7377):376-8. https://doi.org/10.1038/nature1 0590.

3. Warnecke L, Turner JM, Bollinger TK, Lorch JM, Misra V, Cryan PM, et al. Inoculation of bats with European Geomyces destructans supports the novel pathogen hypothesis for the origin of white-nose syndrome. Proc Natl Acad Sci. 2012;109(18):6999-7003. https://doi.org/10.1073/pnas.12003 74109 .

4. Wibbelt G, Kurth A, Hellmann D, Weishaar M, Barlow A, Veith M, et al. White-nose syndrome fungus (Geomyces destructans) in bats, Europe. Emerg Infect Dis. 2010;16(8):1237-43. https://doi.org/10.3201/eid1608.100002.

5. Puechmaille SJ, Wibbelt G, Korn V, Fuller H, Forget F, Mühldorfer K, et al. Pan-European distribution of white-nose syndrome fungus (Geomyces destructans) not associated with mass mortality. PLoS One. 2011:6(4):e19167. https://doi.org/10.1371/journal.pone.0019167.

6. Minnis AM, Lindner DL. Phylogenetic evaluation of Geomyces and allies reveals no close relatives of Pseudogymnoascus destructans, comb. nov., in bat hibernacula of eastern North America. Fungal Biol. 2013;117(9):638-49. https://doi.org/10.1016/j.funbio.2013.07.001

7. Drees KP, Lorch JM, Puechmaille SJ, Parise KL, Wibbelt G, Hoyt JR, et al. Phylogenetics of a fungal invasion: origins and widespread dispersal of white-nose syndrome. mBio. 2017;8:15.

8. Leopardi S, Damer B, Puechmaille SJ. White-nose syndrome fungus introduced from Europe to North America. Curr Biol. 2015;25(6):R217-9. https://doi.org/10.1016/j.cub.2015.01.047.

9. Blehert DS, Hicks AC, Behr M, Meteyer CU, Berlowski-Zier BM, Buckles EL, et al. Bat white-nose syndrome: an emerging fungal pathogen? Science. 2009;323(5911):227. https://doi.org/10.1126/science.1163874.

10. Frick WF, Pollock JF, Hicks AC, Langwig KE, Reynolds DS, Turner GG, et al. An emerging disease causes regional population collapse of a common North American bat species. Science. 2010;329(5992):679-82. https://doi.org/10.112 6/science.1188594

11. Thogmartin WE, King RA, McKann PC, Szymanski JA, Pruitt L. Populationlevel impact of white-nose syndrome on the endangered Indiana bat. J Mammal. 2012;93(4):1086-98. https://doi.org/10.1644/11-MAMM-A-355.1.

12. Francl KE, Ford WM, Sparks DW, Brack V. Capture and reproductive trends in summer bat communities in West Virginia: assessing the impact of whitenose syndrome. J Fish Wildlife Manage. 2012;3(1):33-42. https://doi.org/10.3 996/062011-JFWM-039.

13. Reeder DM, Frank CL, Turner GG, Meteyer CU, Kurta A, Britzke ER, et al. Frequent arousal from hibernation linked to severity of infection and mortality in bats with white-nose syndrome. PLoS One. 2012;7(6):e38920. https://doi.org/10.1371/journal.pone.0038920.

14. Moosman PR, Veilleux JP, Pelton GW, Thomas HH. Changes in capture rates in a community of bats in New Hampshire during the progression of whitenose syndrome. Northeast Nat. 2013;20(4):552-8. https://doi.org/10.1656/04 5.020 .0405 .

15. Reynolds RJ, Powers KE, Orndorff W, Ford WM, Hobson CS. Changes in rates of capture and demographics of Myotis septentrionalis (northern long-eared bat) in Western Virginia before and after onset of white-nose syndrome. Northeast Nat. 2016:23(2):195-204. https://doi.org/10.1656/045.023.0201.

16. U.S. Fish and Wildlife Service. Where is it now? 2019. https://www. whitenosesyndrome.org. Accessed 3 Dec 2020.

17. Powers KE, Reynolds RJ, Orndorff W, Ford WM, Hobson CS. Post-white-nose syndrome trends in Virginia's cave bats, 2008-2013. J Ecol Nat Environ. 2015; 7:113-23.

18. Altringham JD. Bats: from evolution to conservation: Oxford University Press: 2011. https://doi.org/10.1093/acprof:osobl/9780199207114.001.0001. 
19. Brooks RT. Declines in summer bat activity in Central New England 4 years following the initial detection of white-nose syndrome. Biodivers Conserv. 2011;20(11):2537-41. https://doi.org/10.1007/s10531-011-9996-0.

20. Dzal Y, McGuire LP, Veselka N, Fenton MB. Going, going, gone: the impact of white-nose syndrome on the summer activity of the little brown bat (Myotis lucifugus). Biol Lett. 2011;7(3):392-4. https://doi.org/10.1098/rsbl.2010. 0859.

21. Ford WM, Britzke ER, Dobony CA, Rodrigue JL, Johnson JB. Patterns of acoustical activity of bats prior to and following white-nose syndrome occurrence. J Fish Wildlife Manage. 2011;2(2):125-34. https://doi.org/10.3 996/042011-JFWM-027.

22. Johnson JB, Rodrigue JL, Ford WM. Nightly and yearly bat activity before and after white-nose syndrome on the Fernow experimental forest in West Virginia, Research paper. NRS-24. Newtown Square: U.S. Forest Service; 2013.

23. Nocera T, Ford WM, Silvis A, Dobony CA. Patterns of acoustical activity of bats prior to and 10 years after WNS on fort drum army installation, New York. Glob Ecol Conserv. 2019;18:e00633. https://doi.org/10.1016/j.gecco.201 9.e00633.

24. Langwig KE, Frick WF, Bried JT, Hicks AC, Kunz TH, Marm Kilpatrick A. Sociality, density-dependence and microclimates determine the persistence of populations suffering from a novel fungal disease, white-nose syndrome. Ecol Lett. 2012;15(9):1050-7. https://doi.org/10.1111/j.1461-0248.2012.01829.x.

25. Langwig KE, Frick WF, Hoyt JR, Parise KL, Drees KP, Kunz TH, et al. Drivers of variation in species impacts for a multi-host fungal disease of bats. Philos Trans R Soc Lond B Biol Sci. 2016;371(1709):20150456. https://doi.org/10.1 098/rstb.2015.0456.

26. Frank CL, Michalski A, McDonough AA, Rahimian M, Rudd RJ, Herzog C. The resistance of a North American bat species (Eptesicus fuscus) to white-nose syndrome (WNS). PLoS One. 2014;9(12):e113958. https://doi.org/10.1371/ journal.pone.0113958.

27. Lausen CL, Barclay RMR. Benefits of living in a building: big brown bats (Eptesicus fuscus) in rocks versus buildings. J Mammal. 2006;87(2):362-70. https://doi.org/10.1644/05-MAMM-A-127R1.1

28. Dobony CA, Hicks AC, Langwig KE, von Linden Rl, Okoniewski JC, Rainbolt RE. Little brown myotis persist despite exposure to white-nose syndrome. J Fish Wildl Manage. 2011;2(2):190-5. https://doi.org/10.3996/022011-JFWM-014.

29. Pettit JL, O'Keefe JM. Impacts of white-nose syndrome observed during long-term monitoring of a midwestern bat community. J Fish Wild Manage. 2017;8(1):69-78. https://doi.org/10.3996/102016-JFWM-077.

30. De La Cruz JL, Ward RL, Schroder ES. Landscape characteristics related to use of artificial roosts by northern long-eared bats in North-Central West Virginia. Northeast Nat. 2018;25(3):487-501. https://doi.org/10.1656/045.025.0312.

31. Jachowski DS, Dobony CA, Coleman LS, Ford WM, Britzke ER, Rodrigue JL. Disease and community structure: white-nose syndrome alters spatial and temporal niche partitioning in sympatric bat species. Divers Distrib. 2014; 20(9):1002-15. https://doi.org/10.1111/ddi.12192

32. Bradley CA, Altizer S. Urbanization and the ecology of wildlife diseases. Trends Ecol Evol. 2007;22(2):95-102. https://doi.org/10.1016/j.tree.2006.11 001

33. Schimpp SA, Li H, Kalcounis-Rueppell MC. Determining species specific nightly bat activity in sites with varying urban intensity. Urban Ecosyst. 2018; 21(3):541-50. https://doi.org/10.1007/s11252-018-0737-y.

34. Johnson JS, Reeder DM, McMichael JW III, Meierhofer MB, Stern DWF, Lumadue SS, et al. Host, pathogen, and environmental characteristics predict white-nose syndrome mortality in captive little brown myotis (Myotis lucifugus). PLoS One. 2014;9(11):e112502. https://doi.org/10.1371/ journal.pone.0112502.

35. Cheng TL, Gerson A, Moore MS, Reichard JD, DeSimone J, Willis CKR, et al Higher fat stores contribute to persistence of little brown bat populations with white-nose syndrome. J Anim Ecol. 2019;88(4):591-600. https://doi. org/10.1111/1365-2656.12954

36. Kurta A, Teramino JA. Bat community structure in an urban park. Ecography. 1992;15(3):257-61. https://doi.org/10.1111/j.1600-0587.1992.tb00032.x.

37. Gaisler J, Zukal J, Rehak Z, Homolka M. Habitat preference and flight activity of bats in a city. J Zool. 1998;244(3):439-45. https://doi.org/10.1111/j.14697998.1998.tb00048.x.

38. Avila-Flores R, Fenton MB. Use of spatial features by foraging insectivorous bats in a large urban landscape. J Mammal. 2005;86(6):1193-204. https://doi. org/10.1644/04-MAMM-A-085R1.1.

39. Hourigan $\mathrm{CL}$, Catterall $\mathrm{CP}$, Jones $\mathrm{D}$, Rhodes $\mathrm{M}$. The diversity of insectivorous bat assemblages among habitats within a subtropical urban landscape: bat diversity in a subtropical city. Aust Ecol. 2010;35(8):849-57. https://doi.org/1 0.1111/j.1442-9993.2009.02086.x.

40. Jung K, Kalko EKV. Adaptability and vulnerability of high flying Neotropical aerial insectivorous bats to urbanization: responses of insectivorous bats to urbanization. Divers Distrib. 2011;17(2):262-74. https://doi.org/10.1111/j.14 72-4642.2010.00738.x

41. Jung K, Threlfall CG. Urbanisation and its effects on bats-a global metaanalysis. In: Bats in the Anthropocene: conservation of bats in a changing world. Cham: Springer; 2016. p. 13-33.

42. Duchamp JE, Swihart RK. Shifts in bat community structure related to evolved traits and features of human-altered landscapes. Landsc Ecol. 2008; 23(7):849-60. https://doi.org/10.1007/s10980-008-9241-8.

43. Gates JE, Johnson JB. Bat inventories of the national capital region parks final report. Frostburg: University of Maryland Center for Environmental Sciences; 2005.

44. Ingersoll TE, Sewall BJ, Amelon SK. Improved analysis of long-term monitoring data demonstrates marked regional declines of bat populations in the eastern United States. PLoS One. 2013;8(6):e65907. https://doi.org/1 0.1371/journal.pone.0065907.

45. Johnson JB, Gates JE, Ford WM. Distribution and activity of bats at local and landscape scales within a rural-urban gradient. Urban Ecosyst. 2008;11(2): 227-42. https://doi.org/10.1007/s11252-008-0055-x.

46. Coleman LS, Ford WM, Dobony CA, Britzke ER. A comparison of passive and active acoustic sampling for a bat community impacted by white-nose syndrome. J Fish Wildl Manage. 2014;5(2):217-26. https://doi.org/10.3996/082013-JFWM-057.

47. Miller KM, Dieffenbach FW, Campbell JP, Cass WB, Comiskey JA, Matthews $E R$, et al. National parks in the eastern United States harbor important older forest structure compared with matrix forests. Ecosphere. 2016;7:e01404.

48. Dyer JM. Revisiting the deciduous forests of eastern North America. BioScience. 2006:56(4):341-52. https://doi.org/10.1641/0006-3568(2 006)56[341:RTDFOE]2.0.CO;2.

49. Teets KD, Loeb SC, Jachowski DS. Detection probability of bats using active versus passive monitoring. Acta Chiropterologica. 2019;21(1):205. https://doi. org/10.3161/15081109ACC2019.21.1.017.

50. Ford WM, Menzel MA, Rodrigue JL, Menzel JM, Johnson JB. Relating bat species presence to simple habitat measures in a central Appalachian forest. Biol Conserv. 2005;126(4):528-39. https://doi.org/10.1016/j.biocon.2005.07.003.

51. Loeb SC, Rodhouse TJ, Ellison LE, Lausen CL, Reichard JD, Irvine KM, et al. A plan for the North American bat monitoring program (NABat). Asheville: U.S Department of Agriculture Forest Service, Southern Research Station; 2015. https://www.fs.usda.gov/treesearch/pubs/48442. Accessed 27 Sept 2019.

52. U.S. Fish and Wildlife Service. 2018 range-wide Indiana bat survey guidelines. 2018. https://www.fws.gov/midwest/endangered/mammals/ inba/surveys/pdf/2018RangewidelBatSurveyGuidelines.pdf. Accessed 27 Sept 2019

53. Deeley S, Freeze S, Rohrbaugh L. Post-White nose syndrome national capital region bat communities. Natural resource report. Fort Collins: National Park Service; in review.

54. Menzel MA, Menzel JM, Castleberry SB, Ozier J, Ford WM, Edwards JW. Illustrated key to skins and skulls of bats in the southeastern and mid Atlantic states. Newton Square: USDA Forest Service, Northeastern Research Station; 2002

55. Anthony ELP. Age determination in bats. In: Kunz TH, editor. Ecological and behavioral methods for the study of bats. Washington DC: Smithsonian Institution Press; 1988. p. 47-58.

56. Racey PA. Reproductive assessment in bats. In: Kunz TH, editor. Ecological and behavioral methods for the study of bats. Washington, D.C.: Smithsonian Institution Press; 1988. p. 31-43.

57. Colwell RK, Coddington JA. Estimating terrestrial biodiversity through extrapolation. Philos Trans R Soc Lond Ser B Biol Sci. 1994;345(1311):101-18. https://doi.org/10.1098/rstb.1994.0091.

58. Oksanen J, Blanchet FG, Kindt R, Legendre P, Minchin PR, O'Hara RB, et al. vegan: community ecology package. R package version 2.2-1. 2015. http:// CRAN.R-project.org/package=vegan. Accessed 27 Sept 2019.

59. Student WSG. The probable error of a mean. Biometrika. 1908;6(1):1-25. https://doi.org/10.2307/2331554.

60. Zimmerman DW. Teacher's corner: a note on interpretation of the pairedsamples t-test. J Educ Behav Stat. 1997:22:349-60.

61. R Core Team. R: A language and environment for statistical computing. Vienna: R Core Team; 2019. http://www.R-project.org/. Accessed 27 Sept 2019 
62. Niver RA, King RA, Armstrong MP, Ford WM. Methods to evaluate and develop minimum recommended summer survey effort for Indiana bats: white paper. 2014. https://www.fws.gov/midwest/Endangered/mammals/ inba/surveys/pdf/WhitePaperlBatSurveyEffort13Jan2014.pdf. Accessed 27 Sept 2019

63. Ford WM, Silvis A, Rodrigue JL, Kniowski AB, Johnson JB. Deriving habitat models for northern long-eared bats from historical detection data: a case study using the Fernow experimental forest. J Fish Wildl Manage. 2016;7(1): 86-98. https://doi.org/10.3996/012015-JFWM-004.

64. Hoyt JR, Cheng TL, Langwig KE, Hee MM, Frick WF, Kilpatrick AM. Bacteria isolated from bats inhibit the growth of Pseudogymnoascus destructans, the causative agent of white-nose syndrome. PLoS One. 2015;10:12.

65. Frick WF, Cheng TL, Langwig KE, Hoyt JR, Janicki AF, Parise $K L$, et al. Pathogen dynamics during invasion and establishment of white-nose syndrome explain mechanisms of host persistence. Ecology. 2017;98(3):62431. https://doi.org/10.1002/ecy.1706.

66. Arnett EB, Baerwald EF. Impacts of wind energy development on bats: Implications for conservation. In: Adams RA, Pedersen SC, editors. Bat evolution, ecology, and conservation. New York: Springer; 2013. p. 435-56. https://doi.org/10.1007/978-1-4614-7397-8_21. Accessed 3 Apr 2014.

67. Teets KD. Assessment of data collection techniques and white-nose syndrome effects on bat communities of South Carolina. Thesis. Clemson University; 2018. https://tigerprints.clemson.edu/cgi/viewcontent.cgi?article= 4027\&context=all_theses. Accessed 27 Sept 2019.

68. Langwig KE, Hoyt JR, Parise KL, Frick WF, Foster JT, Kilpatrick AM. Resistance in persisting bat populations after white-nose syndrome invasion. Philos Trans R Soc Lond B Biol Sci. 2017;372(1712):20160044. https://doi.org/10.1 098/rstb.2016.0044.

69. Ecological Engineering. Protected bat species survey report: Northern longeared bat research project eastern North Carolina survey phase 1, sessions 1 \& 2: Fall 2015 and Winter 2016. Cary: Ecological Engineering; 2016. TIP No. R-9999 WBS No. 34634.1.4

70. Grider JF, Larsen AL, Homyack JA, Kalcounis-Rueppell MC. Winter activity of coastal plain populations of bat species affected by white-nose syndrome and wind energy facilities. PLoS One. 2016;11(11):e0166512. https://doi.org/1 0.1371/journal.pone.0166512.

71. Hawkings JA, Gooden MK, Sewell PL. Final report: fall 2016/winter 2017 NCDOT northern long-eared bat research project, Bertie, Bladen, Hyde, Martin, and Tyrrell counties, North Carolina. Paint Lick: Cooperhead Environmental Consulting, Inc:; 2017.

72. North Carolina Division of Parks and Recreation. Mammals of North Carolina: their distribution and abundance. 2019. http://www.dpr.ncparks.gov/ma mmals/accounts.php. Accessed 23 Apr 2019.

73. Loeb SC, Post CJ, Hall ST. Relationship between urbanization and bat community structure in national parks of the southeastern U.S. Urban Ecosystems. 2009:12:197-214.

74. Racey PA, Swift SM. Variations in gestation length in a colony of pipistrelle bats (Pipistrellus pipistrellus) from year to year. J Reprod Fertil. 1981;61(1): 123-9. https://doi.org/10.1530/jrf.0.0610123.

75. Grindal SD, Collard TS, Brigham RM, Barclay RMR. The influence of precipitation on reproduction by myotis bats in British Columbia. Am Midl Nat. 1992;128(2):339-44. https://doi.org/10.2307/2426468.

76. Patriquin KJ, Leonard ML, Broders HG, Ford WM, Britzke ER, Silvis A. Weather as a proximate explanation for fission-fusion dynamics in female northern long-eared bats. Anim Behav. 2016;122:47-57. https://doi.org/10.1016/j.a nbehav.2016.09.022.

\section{Publisher's Note}

Springer Nature remains neutral with regard to jurisdictional claims in published maps and institutional affiliations.

Ready to submit your research? Choose BMC and benefit from:

- fast, convenient online submission

- thorough peer review by experienced researchers in your field

- rapid publication on acceptance

- support for research data, including large and complex data types

- gold Open Access which fosters wider collaboration and increased citations

- maximum visibility for your research: over $100 \mathrm{M}$ website views per year

At $\mathrm{BMC}$, research is always in progress.

Learn more biomedcentral.com/submissions 